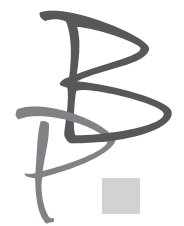

Valeriia Babenko*

Kijowski Uniwersytet im. Borysa Hrinczenki, Ukraina

https://orcid.org/0000-0001-8200-2875

\title{
Трансформації комедії дель арте в контексті сучасного стильового синтезу (на матеріалі п`єси Л. Петрушевської «Квартира Коломбіни»)
}

\author{
Transformations of comedy dell'arte \\ in context of modern stylistic synthesis \\ (on the material of L. Petrushevskaya's play "Columbine's Apartment")
}

Abstract: In the article, the author analyzes the features of comedy dell'arte, the rules of poetic techniques and stylistic synthesis. Attention is drawn to the style and genre of the play, a synthesis of the principles of postmodernism, modernism, and neo-baroque. The main artistic means of the comedy dell'arte are analyzed. The study showed that the basic aesthetic principles of commedia dell'arte are reduced to an aesthetic system that contains three essential elements: first, the theater is held by a professional actor who is fully committed to the theater; secondly, the influence of theater is stronger through the synthesis of arts: plastic, music, dance and words; third, the soul of the play is action.

Keywords: commedia dell'arte, inversion, neo-baroque, comic intrigue, stylistic dynamics.

* Valeriia Babenko - mgr; lektor i wykładowca języka włoskiego w Katedrze Filologii Romańskiej oraz Lingwistyki Porównawczej i Typologicznej Instytutu Filologii Kijowskiego Uniwersytetu im. Borysa Hrinczenki; doktorantka w Katedrze Literatury Ukraińskiej, Komparatystyki i Hrinczenkoznawstwa. Autorka pracy: Prevention of tradition, regularity of positive receives, dell'arte canonical code revaluation („Literary Process”2019). 
Література кінця XX - початку XXI століття демонструє активний пошук, експеримент, діалог із традиціями та інтенції на оновлення.

У загальній зміні естетичних парадигм жанрові та стильові зрушення взаємно віддзеркалюються.

Ці процеси відображають перехідне художнє мислення, притаманне усім видам мистецтва у періоди культурної кризи, до яких і відноситься межа XX - XXI століть. Перехідне художнє мислення має свої закономірності. I сучасні естетика, літературознавство, культурологія намагаються виокремити коло типологічних рис цього феномену (монографії М. Хрінова, Г. Мережинської, збірник праць «Перехідні процеси в російській художній культурі: Новий і Новітній час») та їх реалізацію у конкретних родах літератури, зокрема, в драматургії двох кризових періодів - меж XX соліття (праці О. Бондаревої, Є. Васильєва, О. Когут, Н. Малютіної, Т. Свербілової, М. Шаповал).

Однією з таких рис є інверсія, тобто реактуалізація, повторне звернення до «старих» жанрових, стильових настанов, до забутих i, начебто, «відпрацьованих» художніх систем.

Реалізацією саме такої тенденції є посилення інтересу митців до «старого» жанру commedia dell arte, який, за думкою дослідників сформувався у XVI столітті, згасав у XVIII і остаточно втратив позиції у XX - му столітті, перейшовши, за думкою Патріса Павіса, у бурлескний кінематограф і клоунаду. Але одночасно «старий» жанр став свого роду орієнтиром, тобто набув символічних смислів. Підтвердження цієї позиції зустрічаємо у характеристиці сучасного ставлення до жанру, яку дає видатний дослідник театру, акцентуючи, на наш погляд, перспективу розвитку форми: «Підготовка акторів commedia dell arte стала моделлю синтетичного театру, із його орієнтацією на універсального актора та акторський ансамбль, театру, який знову відкриває виражальні можливості акторського жесту та імпровізації (Мейєрхольд, Копо, Дюллен, Барро») $)^{1}$

1 П. Павис, Словарь театра, Пер. С фр.; Под ред.. Л. Баженовой., М.: Узд-во «ГИТИС», 2003, c. 192-193. 
Огляд наукової літератури з досліджуваного питання, а саме: тяглість традиції, закономірності поетичних прийомів, переосмислення канонічного коду dell'arte. Жанрова трансформація commedia civile rusticale y commedia dell'arte в італійській драматургії (О. Галич, Є.І. Гапонов, Е. Гротовський, О.К. Дживєлєгов, В.І. Кузін, Д.О. Флеєнко, Т. Шабаліна, С. Мацоні, А. Перутелі та ін.) дає можливість стверджувати, що в сучасному літературознавстві даній проблемі приділено недостатньо уваги.

Можна припустити, що комедія дель арте зараз сприймається як архетип театральності, одна із складових міфу про мистецтво сцени. Про це свідчить повернення інтересу до жанру у кінці XX - початку XXI століття, тобто відкидання занепаду й вічна актуальність. У цьому процесі ре актуалізації взірець не відтворюється повністю, а зазнає трансформацій і модифікацій. Здійснюється обігравання жанрового коду, його травестія, провокаційна реконструкція, що притаманно модернізму і постмодернізму, тобто жанрові зміни відображають стильовий пошук й оновлення художніх парадигм.

Це явище спостерігається у багатьох національних літературах двох меж XX століття. Зокрема, відбувається перенесення уваги з традиційної акторської імпровізації на сам принцип «маски», що сприяє загостренню соціальних і екзистенціальних проблем, відбиває притаманний перехідному мисленню перегляд картини світу й філософської концепції людини. I у цьому проявляється новизна, базована на художньому потенціалі самого жанру. «Адже і для італійської народної комедії маска означала не лише пристрій, що актор вдягав на обличчя, але й певний соціально-психологічний тип. I для мистецтва XX - початку XXI століття тема маски («личини»)і сутності людини («лику») є однією 3 найбільш репрезентативних ( драматургія А. Жаррі, Л. Піранделло, В.Б. Сйтса, М. де Гельдерода, Б. Брехта, Ж. Кокто, Ю.О`Ніла, Г. Горіна, режисура Вс. Мейєрхольда, Є. Вахтангова, Ж-Л. Барро, Ш. Дюллена, А. Мнушкіної, М. Кімова)»².

Трансформації комедії дель арте відбуваються у тісному зв`язку із стильовою динамікою, зокрема із впливом естетики постмодернізму,

2 Є.М. Васильєв, Сучасна драматургія: жанрові трансформачії, модифікаиії, новаиії: монографія, Луцьк: ПВД «Твердиня», 2017, с. 369-370. 
а в українській і російській його «версіях» демонструється й повернення до «не вивчених уроків» модернізму, за словами М. Ліповецького ${ }^{3}$, тобто, штучно перерваного розвитку, послідовної зміни систем. Спостерігається також оновлення традицій бароко.

Виокремлення й вивчення векторів трансформації «архаїчного» жанру в контексті зміни стильових парадигм є актуальною науковою задачею. Метою нашого дослідження є вивчення взаємодії процесів жанрової трансформації й стильового синтезу у творі класика ХХ століття Л. Петрушевської «Квартира Коломбіни».

Творчість Л. Петрушевської достатньо вивчена, але переважно у координатах естетики «нової хвилі», до якої, власне, й належать твори митця 1970-1980-х років. «Нову хвилю» в російській і українській літературі вчені вважають перехідним явищем між соцреалізмом і постмодернізмом ${ }^{4}$ «Нова хвиля» заперечувала і дискредитувала соцреалізм на рівнях ідей, тематики (введення табуйованих тем), образному (герой-невдаха), модальності («жах повсякденності», мотив смерті, трагізм людського буття, апокаліптичні передчуття), художніх прийомів.

Одним з головних принципів комедії дель арте була імпровізаційність. В основі твору лежав сценарій (лібретто), що мав лише стислу сюжетну схему. Протягом сценічної дії сценарії розширювалися завдяки імпровізаційним обробкам виконавців. Звичайно, імпровізація потребувала особливого узгодження між акторами, що нині йменується ансамблевістю. До того ж, імпровізація в комедії масок не обмежувалася створенням сценічного тексту. Вона визначала й пантоміміку вистави, яка відобразилась у всіляких буфонадах (так званих «лацці»).

У «Квартирі Коломбіни» естетика «нової хвилі» долається. Жах повсякденності відображено частково, знижено до побуту (дефіцит, отруйні страви з кулінарії), радянська ідеологія подана як ідіотична, герой-невдаха

3 М. Липовецкий, Голубое сало» поколения, или Два мифа об одном кризисе, „Знамя” 1999, №11, c. 206-216.

4 О. Бондарева, Міф і драма у новітньому літературному контексті: поновлення структурного діалогу через жанрове моделювання. Монографія, «Четверта хвиля» 2006. Л. Бондар, Творчість Ярослава стельмаха в контексті «нової хвилі» української драматургії 80-х років XX століття. Автореф. дис. На здобуття наук. ступеня канд.. філол.. наук. 10.01.01. Херсон: Херсонський держ. університет 2007, 20 с. 
замінений цілеспрямованим , таким, що себе активно утверджує у досягненні невисоких цілей, але прикривається високим мистецтвом. Загальна модальність твору не трагічна, а комічна. Таке перевертання парадигми «нової хвилі свідчить про пошук драматургом нових векторів розвитку мистецтва й інтенцію на оновлення стилю.

І вибір для цього саме комедії дель арте видається виправданим. Комедія в цілому, за Патрісом Павісом, сприяє оновленню драматургії: «На відміну від трагедії, комедія нічого не має проти очуднення і залюбки використовує елементи само пародії, розкриваючи у такий спосіб свої прийоми і художній метод. До того ж, це один із жанрів, якому притаманний високий рівень самосвідомості, комедія часто функціонує як метамова критики і як театр у театрі» 5 .

Саме цю якість - металітературності, авторефлексії мистецтва - відображає «Квартира Коломбіни». Це п`єса про театр, акторів які й звичайне поза сценічне життя (зваблення, сімейний побут і безлад) та соціальні інститути (комісію по роботі з молоддю, громадські навантаження на кшталт інтернаціональної дружби, листування школярів із моряками Мозамбіку тощо) перетворюють на театр, виставу. Невідповідність дискурсів, з одного боку, мистецтва, а з іншого - ідеології, побуту та й сама поведінка дійових осіб, їх знетронення породжують комічний ефект.

Вибір Л. Петрушевською жанрового орієнтиру комедії дель арте пояснюється й тим, що жанр асоціюється із підвищеною театральністю, базується на масці й вільній імпровізації акторів. Тому ця форма максимально вивищує інтенції на вільний експеримент і оновлення , на зміну жанрових і стильових парадигм, максимально загострює авторефлексію мистецтва. Саме вільну, комічну імпровізацію, безкінечні варіації прочитання усталеної інтриги між традиційними масками вчені вважають оновлюючим потенціалом комедії дель арте: «вона викриває застарілі форми та грає роль каталізатора в оновленні театру, відаючи пріоритет грі та театральності» ${ }^{6}$.

У творчості Л. Петрушевської «Квартира Коломбіни» стає вододілом між періодом «нової хвилі» і постмодерністським експериментом, для чого

5 П. Павис, Словар театра, с. 184.

6 Там же, с. 193 
були передумови кристалізовані в індивідуальному стилі письменниці: сприйняття й зображення життя як абсурду, хаосу, мовна гра, моделювання образів екзістенціально дезорієнтованих особистостей тощо. Вчені відзначають такі складові ідеостилю, як «естетичний екстремізм» ${ }^{7}$, послідовний відхід від канону класичної драми, клаптиковість фігур і композиції

До елементів постмодернізму у творі відносимо: діалогічність (драматург веде діалог із класичною традицією, старим жанровим орієнтиром), інтертекстуальність (реалізована у комічному ключі травестії творів Шекспіра і Грибоєдова), гру (весь твір побудований на спонтанній імпровізації , яку породжує традиційна інтрига зваблення й викривання), іронію та провокаційну децентрацію (дійові особи прагматично ставляться до літературної класики і театру як символу мистецтва, використовують їх у побутових цілях і тим і знімають владний дискурс вічного мистецтва). Постмодерною за духом $є$ й сміхова модальність твору, адже постмодернізм із його тотальною іронією та компромісністю уникає трагедії. Ця особливість чітко проводить межу між естетикою жахливого у ранніх творах Петрушевської і «Квартирою Коломбіни». Сміхове начало розповсюджується і на інтерпретацію самої форми комедії дель арте, за думкою А. Самаріна, цей жанр піддається травестії, адже «твір одужує як соціальні реалії пізнього «застою», так і класичний канон, висвічує невідповідності між сучасністю та ідеальним світом. Традиційні амплуа і любовна інтрига комедії дель арте зберігаються, але у них вносяться елементи новизни: висвітлюються реалії сучасності, суперечливі за своєю сутністю моделі даного жанру, що посилює комічний ефект»9.

Твір відображає і модерністські настанови, що в цілому притаманне російській і українській «версіям» постмодернізму ${ }^{10}$. Зокрема, актуалізу-

7 Р. Тименчик, $T b l-ч m o ?$ Или Введение в театр Петрушевской; [в:] Петрушевская Л. Три девушки в голубом. М., 1989, с. 398.

8 О.В. Богданова, Постмодернизм в контексте современной русской литературы (60 90-е годы XX века - начало XXI века), СПб: Филол. Ф-т С.-Петерб. Гос. Ун-та, 2004, с. 616-617.

9 А.М. Самарін, Стратегії перекодування класики в російській драматургії на межі XX - XXI століть. Автореф. Дис. На здобуття наук. ступеня канд.. філол.. наук. 10.01.02 - російська література. - Херсон: Херсонський державний університет, 2011, с. 9.

10 А.Ю. Мережинская, Русская постмодернистская література. Учебник. - К.: ИПЦ «Київський університет», 2007. 
ється модель митця. Увага до творчої особистості як до знакової фігури епохи притаманна перехідному мисленню в цілому. У п’єсі маску Коломбіни автор віддає пристарілій актрисі, примі, яка відібрала собі усі ролі молодих героїнь (Джульєтту, як і Ромео, Гамлета вона називає «віковими» ролями, до яких треба дослужитися років двадцять-тридцять), вона розповсюдила свої владні зазіхання й на інші сфери: зваблює режисера, посягає на молоденького актора, царює у громадському житті у ролі голови комісії із роботи з молоддю. Маску Пьєро носить інфантильний та амбітний актор, який поки що грає Котика, але бореться усіма засобами за головні ролі шекспірівських п`єс. Маска Арлекіна дістається режисеру, владному й хтивому, який травестує класичний спадок своїм невіглаством і обмеженістю. Петрушевська, фактично, виводить театральні типи й глузує з них. На відміну від моделей, представлених у символізмі (високого митця, демонічного поета, медіума, посередника між світами) дійові особи «Квартири Коломбіни» - це фігури травестійні, комічні, їх приналежність мистецтву суто зовнішня. Отже, модерністський взірець перевертається. На перший план виходить проста інтрига, в якій мистецтво - це лише засіб самоутвердження і використання службового становища задля спокушання, а крім того, ідеологічний дискурс вивищується над театром, тобто тимчасове відсуває вічне. У межах типової для комедії дель арте інтриги Коломбіна перебирає на себе функції ще однієї маски «хтивого старого» й заманює до дому юного актора. Репетиції Ромео i Джульєтти стають лише привидом до зближення (традиційним для комедії переодяганням чоловіка у жіночий, жінки - у чоловічий, кві про кво, поцілунків, дотиків, грубих жартів) й домовленостей щодо обміну сексу на кар'єрний зріст. Передчасна поява в дому чоловіка - режисера Арлекіна, теж «хтивого старого» (ця маска подвоюється) лише стимулює імпровізації-виправдання й імпровізації репетиції (оскільки ніхто 3 «театральних діячів» не знає текстів «Ромео и Джульєтти» та «Гамлету» й фантазує від себе). Ситуація перевертається і Арлекін сам починає керувати «репетицією», тобто вчити цілуватися й починає зваблювати П єро, причому чоловіча чи жіноча природа молодого актора, зізнання Коломбіни не заважають процесу й лише надихають «митця». Ревнива Коломбіна знаходить єдиний вихід із глухого кута: перериває «репетицію» й відкриває збори колективу. Тобто ідеологічний момент виконує функцію 
античного «бога 3 машини». Коломбіна змінює роль спокусниці на роль громадського діяча, адміністративним шляхом видаляє з зали (як кворум задіяні глядачі, тобто моделюється «театр у театрі») юного суперника й за допомогою лестощів та адміністративного тону повертає собі «генія»режисера (алюзія на Аркадіну з «Чайки» А.Чехова).

Комічна інтрига має глибинний підтекст, у якому розгортається конфлікт цінностей: зіткнення високого мистецтва (його репрезентанти традиція комедії дель арте, Шекспір, Чехов, Грибоєдов) і агресивного невігластва, ідеологічного дискурсу. Фактично п`єса відбиває авторську рефлексію культурної кризи. Шляхи їі подолання моделюються у сприйнятті глядачів в апофатичний спосіб, тобто від протилежного, від заперечення до утвердження високого статусу мистецтва. Вектор інтерпретації такий: від травестійного зображення культурного невігластва й симуляції (мотив «сценічна неправда!») до відтворення ефекту магії театру, віддзеркаленої у формі комедії дель арте із ії свободою імпровізації та оптимізмом. Отже у підтексті моделюється модерний за духом проект оновлення світу завдяки мистецтву.

У «Квартирі Коломбіни» знаходимо також риси необароко, яке сучасні дослідники вважають або розгалуженням постмодернізму, або ж окремою стильовою течією, що відображає перехідне мислення й демонструє його історичні ритми, типологічну схожість художніх пошуків різних кризових епох ${ }^{11}$.

Особливості необароко органічно входять у ідеостиль Л. Петрушевської із притаманними драматургові контрастним мисленням, парадоксальністю, абсурдизацією, інтерпретацією світу як «перевернутого», неправильного.

На рівні художніх принципів і форми виокремлюються такі необарокові рисами «Квартири Коломбіни»: підвищена театральність (формула «життя театр»), естетика повторів, надмірність деталей. На рівні образів - «монструозність» дійових осіб. Еротична, карнавальна стихія твору, велика кількість смішних жартів, витівок, бутафорських деталей (напри-

11 O. Calabrese, Neo-Baroque:A Sing of the Times, Princeton: Princeton University Press, 1992. P. L. Barnhofen, Cosmography and Chaography: Baroque to Neobaroque. A Stady in Poetics and Cultural Logic: A Dissertation... for the Degree of Doctor of Philosophy (Comparative Literature), University of Wisconsin-Madison, 1995. 
клад, намертво приклеєний, щоб не вкрали у гуртожитку, «реквізит» кошачі вуса, з якими П єро зображує Джульєтту, юну актрису, глядача; жіноча білизна великих розмірів як костюм для Афелії тощо), наявність «репетицій», що можуть розглядатися як інтермедії, все це відбиває орієнтації драматурга і на традиції низового бароко.

Виявлені показові кореляції між трансформаціями комедії дель арте i стильовими пошуками, обидва явища відбивають перехідне художнє мислення, зокрема, інверсію, діалог із класикою, перегляд естетичних орієнтирів, зростання авторефлексії літератури.

Комедія дель арте у творчості Л. Петрушевської з являється саме на етапі зміни художніх парадигм. Драматург відходить від естетики «нової хвилі» у бік постмодерністських експериментів із притаманними саме «слов янській версії» стилю актуалізацією модерністських настанов и особливостей необароко.

Жанровий код комедії дель арте трансформується завдяки очудненню (використанням «старого» коду для зображення сучасності), травестії.

Синтез принципів постмодернізму, модернізму, необароко корелює із особливостями індивідуального стилю драматурга: тенденціями до театралізації, абсурдизації, контрастного зображення реальності, авторефлексії, націленості на експеримент і провокацію, загострення конфлікту ідеалу і деформованої реальності, «перевернутого» світу.

Подібні стратегії оновлення літератури через використання елементів комедії, фарсу, трагіфарсу, прийомів «подвійної сцени», стильового синтезу використовувалися письменницею і у 2000-ні , на нових рубежах творчої динаміки драматурга. Перспективним у цьому аспекті може бути вивчення пізніх творів - «Співак Співачка» і «Біфем», які теж мають окремі риси комедії дель арте. 
Waleria Babenko, Transformations of comedy dell'arte in context of modern stylistic synthesis...

\section{Література}

Богданова О.В. Постмодернизм в контексте современной русской литературы (60 - 90-е годы XX века - начало XXI века) - СПб: Филол. Ф-т С.-Петерб. Гос. Ун-та, 2004. - 716 с.

Бондар Л. Творчість Ярослава Стельмаха в контексті «нової хвилі» української драматургії 80-х років XX століття. Автореф. дис. На здобуття наук. ступеня канд.. філол.. наук. 10.01.01 - українська література. - Херсон: Херсонський держ. університет, 2007. - 20 с.

Бондарева О. Міф і драма у новітньому літературному контексті: поновлення структурного діалогу через жанрове моделювання. Монографія. - К.: «Четверта хвиля», 2006. - 512 с.

Васильєв Є.М. Сучасна драматургія: жанрові трансформації, модифікації, новації: монографрія / Є.М. Васильєв. - Луцьк: ПВД «Твердиня», 2017. - 532 с.

Когут О. Архетипні сюжети в сучасній українській драматургії: Монографія. Рівне: НУВГП, 2010. - 440с.

Липовецкий М. «Голубое сало» поколения, или Два мифа об одном кризисе // Знамя. - 1999. - №11. - С. 206 - 216.

Малютіна Н. П. Українська драматургія кінця XIX - початку XX століття: аспекти родо-жанрової динаміки. - Одеса, Астропринт, 2006.

Мережинская А.Ю. Художественная парадигма переходной культурной епохи. Монографія. Русская проза 80 - 90-х годов XX века. - К.: ИПЦ «Киевский університет», 2001. - 433 с.

Мережинская А.Ю. Русская постмодернистская література. Учебник. - К.: ИПЦ «Київський університет», 2007. - 335 с.

Павис П. Словарь театра / Пер. С фр.; Под ред.. Л. Баженовой. - М.: Узд-во «ГИТИС», 2003. - 516 с.

Петрушевская Л. Квартира Коломбины // Петрушевская Л. Квартира Коломбины. - СПб.: Амфора, 2007. - С.300 - 316.

Самарін А.М. Стратегії перекодування класики в російській драматургії на межі XX - XXI століть. Автореф. Дис. На здобуття наук. ступеня канд.. філол.. наук. 10.01.02 - російська література. - Херсон: Херсонський державний університет, 2011. - 19 с.

Свербідова Т. Г. Такі близькі, такі далекі ...(Жанрові моделі української та російської драми від модерну до соцреалізму в аспекті порівняльної поетики): 
[монографрія[ / Т.Г. Свербілова; [наук. ред.. Д.С. Наливайко]. - Черкаси: ТОВ «МАКЛАУТ», 2011. - 566 с.

Тименчик Р. Ты - что? Или Введение в театр Петрушевской // Петрушевская Л. Три девушки в голубом. М., 1989.

Хренов Н.А. Культура в епоху социального хаоса. Монограсрия. - М.: Едиториал УРСС, 2006. - 448 с.

Шаповал М. Інтертекст у світлі рампи: між текстові та міжсуб єктні реляції української драми: монографія / Мар`яна Шаповал. - К.: Автограф, 2009. - 352 с.

Barnhofen Patricia Lynn. Cosmography and Chaography: Baroque to Neobaroque. A Stady in Poetics and Cultural Logic: A Dissertation ... for the Degree of Doctor of Philosophy (Comparative Literature). University of Wisconsin-Madison, 1995.

Calabrese Omar. Neo-Baroque:A Sing of the Times. Princeton: Princeton University Press, 1992.

\section{Bibliografia}

Barnhofen P. L., Cosmography and Chaography: Baroque to Neobaroque. A Stady in Poetics and Cultural Logic: A Dissertation ... for the Degree of Doctor of Philosophy (Comparative Literature). University of Wisconsin-Madison, 1995.

Bohdanowa O. W., Postmodernyzm w kontekste sowremennoj russkoj łyteraturb (60 - 90-e hodы CHCH weka - naczało XXI weka), SPB: Fyłoł. F-t S.-Peterb. Hos. Un-ta, 2004.

Bondar Ł., Tworczist' Jarosława stelmacha w konteksti «nowoji chwyli» ukrajinśkoji dramaturhiji 80-ch rokiw $\mathrm{CHCH}$ stolittia. Awtoref. dys. Na zdobuttia nauk. stupenia kand. fiłoł.. nauk. 10.01.01 - ukrajinśka literatura. - Cherson: Chersonśkyj derż. uniwersytet, 2007.

Bondarewa O., Mif i drama u nowitńiomu literaturnomu konteksti: ponowłennia strukturnoho diałohu czerez żanrowe modeluwannia. Monohrafija, K.: «Czetwerta chwyla», 2006.

Calabrese O., Neo-Baroque:A Sing of the Times. Princeton: Princeton University Press, 1992.

Chrenow N. A., Kultura w epochu socyalnoho chaosa. Monohrafyja, M.: Edytoryał URSS, 2006.

Kohut O., Archetypni siużety w suczasnij ukrajinśkij dramaturhiji: Monohrafija, Riwne: NUWHP, 2010. 
Łypoweckyj M., «Hołuboe sało» pokołenyja, yły Dwa myfa ob odnom kryzyse, „Znamia" 1999, №11.

Malutina N. P., Ukrajinśka dramaturhija kincia XIX - poczatku CHCH stolittia: aspekty rodo-żanrowoji dynamiky, Odesa, Astroprynt, 2006.

Mereżynskaja A. Ju., Chudożestwennaja paradyhma perechodnoj kultutnoj epochy. Monohrafija. Russkaja proza 80 - 90-ch hodow CHCH weka, K.: YPC «Kyewskyj uniwersytet», 2001.

Mereżynskaja A. Ju., Russkaja postmodernystskaja literatura. Uczebnyk, K.: YPC «Kyjiwśkyj uniwersytet», 2007.

Pawys P., Słowar teatra, per. s fr.; pod red.. Ł. Bażenowoj, M.: Uzd-wo «HYTYS», 2003.

Petruszewskaja Ł.. Kwartyra Kołombyny, [w: Petruszewskaja Ł., Kwartyra Kołombyny, SPB. Amfora, 2007.

Samarin A. M., Stratehiji perekoduwannia kłasyky w rosijśkij dramaturhiji na meżi XX-XXI stolit'. Awtoref. Dys. Na zdobuttia nauk. stupenia kand. . fiłoł.. nauk. 10.01.02 - rosijśka literatura. - Cherson: Chersonśkyj derżawnyj uniwersytet, 2011.

Swerbidowa T. H., Taki błyźki, taki dałeki ...(Żanrowi modeli ukrajinśkoji ta rosijśkoji dramy wid modernu do socrealizmu w aspekti poriwnialnoji poetyky): [monohrafija]. Czerkasy: TOW «MAKŁAUT», 2011.

Szapował M., Intertekst u switli rampy: miż tekstowi ta miżsub 'iektni relaciji ukrajinśkoji dramy: monohrafija, K. Awtohraf, 2009.

Tymenczyk R., Ty - czto? Yły Wwedenye w teatr Petruszewskoj, Petruszewskaja Ł., Try dewuszky w hołubom. M., 1989.

Wasyliew J. M., Suczasna dramaturhija: żanrowi transformaciji, modyfikaciji, nowaciji: monohrafija, - Łućk: PWD «Twerdynia», 2017. 